\title{
THE IMPACT OF IFRS ADOPTION ON EARNINGS MANAGEMENT IN BANKING COMPANIES IN INDONESIA STOCK EXCHANGE
}

\author{
Prima Santy \\ Tawakkal \\ Grace T. Pontoh \\ Department of Accounting, Faculty of Economics, Hasanuddin University \\ Makassar, South Sulawesi
}

\begin{abstract}
The issue of the IFRSadoption as a standard that can lead to a reduction of earnings management. The research aimed to give empirical evidence concerning the impact of the IFRS adoption on earnings management, and the test of the difference level of earnings management between before and after the IFRS adoption. The research scope focused on the implementation of IFRS adoption particularly in PSAK No. 50 and PSAK No. 55 (revised 2006) concerningfinancial instruments. The research objects were the banking companies listed in Indonesia Stock Exchange for 4 years (20082011), i.e. as many as 23 banks. Samples were taken by using the purposive sampling technique. The main variables in this research are IFRS and earnings management,and includes several control variable, among others are, size, financial leverage, market to book value and institutional investors. The data were analyzed usingmultiple regression analysis and different $t$-test analysis. The research result indicates that the IFRS adoption has not effect the decreaseon the earnings management.Among the four control variables, the variable institutional investor is found not to have theeffect on earnings management, whereas the other three variables haveeffect.The result of the different $t$-test analysis also indicates that statistically there is not significant difference on the level of the earnings management between before and after IFRS adoption. Thus, based on this study concluded that the adoption of IFRS still allow for the occurrence of earnings management.
\end{abstract}

Keywords: adoption of IFRS, earnings management, banking companies

\section{INTRODUCTION}

The banking sector is a sector that is quite susceptible to the occurrence of earnings management. The research shows that among the various sectors of existing businesses, earnings management is often found in the banking sector. Suprayitno cited in Haryono (2008) asserts that the adverse selection and moral hazard into reality that is very common in the world of banking. Macey et al. (2003) also noted differences between the characteristics of the banking industry with other industries is that the bank is a business sector that is "not transparent" to allow the agency problem. In theory, the agency problem described in agency theory (Jensen et al., 1976) which states that if there is a separation between the owner as a principal and an agent manager to run the company will display the agency problem because each party will always try to maximize the function utility. In positive accounting theory andeconomic consequencestheory also supports of earnings management and the description of one of the 
association's policy or regulatory accounting rules. Sulistyanto (2008) argued that the existence of rules in accounting standards may constitute one of the tools that accommodate and facilitate corporate fraud. Companies can hide the fraud by using a variety of methods and procedures contained in the accounting standards, thus accounting standards as if to accommodate and allow companies to organize and manage the company's profit in accordance with the objectives to be achieved. Ayres cited in Rahmawati et al. (2001) also describes the factors that drive the action of earnings managementother than the accrual management and implementation of accounting standard policy, a change in accounting standards could also encourage to earnings management.

Efforts toreduce earnings management is eventually seen as an attempt to correct the accounting standards. Improvements in accounting standards currently being an issue is the International Financial Reporting Standards (International Financial Reporting Standard or IFRS). Cai et al. (2008) reveals one of the issues of the International Accounting Standards Board (IASB) is an international standard that aims to removes many allowable accounting alternatives, and is expected to limit the managements' discretion to manipulate earnings, thereby improving earnings quality.
In Indonesia, the adoption of IFRS also began to receive attention and becomes an interesting thing. Revision by revision made to PSAK in adopting IFRS,two of the PSAK arePSAK No.50 (revised 2006) concerningthe presentation and disclosure of financial instruments and PSAK No. 55 (revised 2006) concerning the recognition and measurement of financial instruments. Both the PSAK is effective from January 1, 2010. Theimplication ofthe both PSAKrevised the IFRS adoption is in the banking sector by Caratri (2011), namely the loan loss provisioning or the allowance for impairment losses. According Caratri (2011), banks demanded more rigorous in determining the allowance for impairment losseswith the implementation of PSAK No. 50 and PSAK No. 55 (revised 2006). Thus, both of the two PSAKimplementationcan avoid such gab, banks can not manage amount of the earnings. Transparency of financial reporting bank will also increase and reduce the chance of bank management do earnings management. This is also supported by research that has been done in examining the effect of IFRS on earnings management in both developed countries and developing countries, some of them were by Oriol et al. (2005), Ewert et al. (2005), Daske et al. (2006), Hung et al. (2007), Soderstrom et al. (2007), Barth et al. (2007) and Cai et al. (2008). There is also research that suggests the contrary that there is no decrease in the earnings management. This is taking by 
determinant of other factors in addition to the adoptionof IFRS that may affect earnings management, such as firm size, institutional ownership, economic conditions and market developments and regulatory (Ball et al., 2000 and 2003; Lin et al., 2006; Burgstahler et al., 2006; Ding et al., 2007; Soderstrom et al., 2007; Callao et al., 2010; Tsalavoutas, 2010, and Rudra, 2011). Some further research is also done by looking at the difference level of earnings management between before and after the IFRS adoption, such as Christensen (2008); Jeanjean et al. (2008); Callao et al. (2010), and Lippens (2010). These research also show the diversity in the research results.

Particularly in Indonesia, The research scope focused on the implementation of IFRS adoption particularly in PSAK No. 50 and PSAK No. 55 (revised 2006) concerningfinancial instrumentson the earnings management in banking sector thatis still a little to do, one of them by Anggraita(2012). This research refers toRudra (2011) on 76 companies in the banking and financial sector of India. Previous research (Rudra, 2011) using the model of aggregate accruals approach Jonesmodification, while in this research using the model of specific accrual approach Beaver et al. (1996). Based on the description, the research hypothesis is formulated as follows: Is the adoptionof IFRSaffectthe earnings management? Is there a difference between the level of earnings management before and after IFRS adoption?

Thus, the aim of this study was to obtain empirical evidence about the effect of the adoption of IFRS on the earnings management. Then, also to obtain empirical evidence of earnings management level difference between before and after the adoption of IFRS.

\section{THEORETICAL AND HYPOTHESESDEVELOPMENT}

The background theory used the earnings management is agency theory. This theory explains the relevance of contracts agreements and conflicts of interest that can motivate earnings management that generally filed in two things about solving the agency problem between the principal and the agent, through monitoring and bonding. The principal can limit divergences from his interest by establishingappropriate incentives for the agent and by incurring monitoring costs designed to limit theaberrant activities of the agent. Principals will also pay the agent to expend resources (bonding costs) to guarantee that the agent will not take certain actions which would harm the principal or to ensure that the principal will be compensated if it is done. Term monitoring includes more than just measuring and observing the behavior of agents, but also include for control agent behavior, for example through budget 
restrictions, compensation policies operating rules, etc. Bonding costs incurred to establish and adhere to a mechanism that ensures that the agent acting for the benefit of the principal, such as increasing dividend payments and total debt/financing. (Jensen et al., 1976)

Some other theories such as the positive accounting theory also supports the explanation of the effect of the bonus plan, the existence of debtequity and political coststhat motivateson earnings management measures and the theory of economic consequencesthat support the explanation regulation or policy relevance of accounting ruleson earnings management. The main purpose is to explain the positive accounting approach and predicts the standard choice by management to analyze the costs and benefits of certain financial disclosures related to various individuals and resource allocation in the economy (Belkaoui, 2001:108). Scott (1997:186) defines economic consequences as an accounting policy choices that can affect the value of the company.

Healy et al. (1998) stated that the definition of earnings management contain some aspects. First, earnings management interventions over financial reporting can be done with the use of judgment, such judgment required in estimating the amount of future economic events to be shown in the financial statements, such as thejudgment in determining credit losses and impairment asset. Second, the manager has the option of accounting methods, such as the choice in the method of depreciation or the cost method.

Healy (1985) also stated that the two approaches can be used to detect behavior management is done on earnings management through the control type of accruals and changes in accounting policies. Accrual is broadly defined as the portion of item receipt and expenditure (revenue and expenses) in the income statement, which is not presented by cash flow. Discretionary accruals are used as a proxy for total accruals can be calculated, which one of them through any changes in balance sheet accounts that are the subject accrual. Accrualpolicy can be detectedthrough increased net accounts receivable. This increase is assumed to come froma decrease allowance receivables that result from the estimate. This is due to discretionary accruals management can flexibly control the amount of allowance for receivables accounts, or because of credit policies and records of receivablesamounts at the beginning and the end of the year.

Anggarita (2012) describes the effect of PSAK No. 50 and PSAK No. 55 (Revised 2006) concerning financial instruments is the adoption of IFRSeffect on the banking sector, especially related to the creditallowance for impairment losses (allowance for impairment). Previous calculations allowance for impairment under the provisions of Bank Indonesia Regulation (No. 7/2/PBI/2005 and 
amendment

No.8/2/PBI/2006,

No. 9/6/PBI/2007, and No. 11/2/PBI/ 2009). In this rule set criteria for determining the credit quality (current, substandard, doubtful, and loss) and its percentage of reserves required for each credit quality classification, while based on the impact of of PSAK No. 50 and PSAK No. 55 (Revised 2006) gives more emphasis on objective evidence that the basis of the decline in value and also emphasize that the evaluation will be a reduction was made at each balance sheet date. The calculation of the estimated allowance for impairment that do require data on probability of default and historical loss of at least 3 years back and needed historical loss data had experienced financial assets with credit risk characteristics similar to the characteristics of the credit risk of the financial assets. In addition to an impact on the determination of the allowance for impairment (loan loss provision), the impact of PSAK No. 50 and PSAK No. 55 (Revised 2006) is also the treatment of certain investment securities related to the issue reclassification of financial instruments between tighter.

H1: adoptionof IFRS negatively affecton earnings management

Other researchs also support the results of research on the differences in the level of earnings management before and after the IFRS adoption.Christensen et al. (2008) who found that there is a decrease in earnings management after the adoption of IFRS, especially for companies that implement themvoluntarily. Research results showed that there were significantly decreased after the adoption of accrual earnings management than before the implementasion of the adoption of IFRSvoluntarily. Similarly, by Barth et al. (2007), Lippens (2010) and Jeanjeanet al. (2008) also showed a difference in the level of earnings management before and after IFRS adoption.

$\mathrm{H} 2$ : there are differences in the level of earnings management before and after the IFRS adoption.

\section{MATERIALS AND METHODS}

\section{The location and design of the study}

The research was conducted at the Indonesia Stock Exchange (IDX). Type of research is hypothesis testingto test the relationship of all the variables studied (causal research). Stages of testing the hypothesis in this research is divided into two parts: first, estimate the total accruals and discretionary accruals separate component of nondiscretionary component of accruals. Then, do a regression component of discretionary accruals (a proxy for earningsmanagement value) with the independent variable (IFRS) and several control variables. Secondly, done by testing the difference between the level of earnings management before and after the IFRS adoption.

\section{Variables and measurement}


This study uses three types of variables: independent, dependent and controlvariable. The independent variables used are IFRS. Measurement of this variable using a dummy variable, given the value of zero if the company has not applied IFRS and the value of one if it is to implement IFRS. The implementation of IFRS are referred tothe adoption of IFRS in particular with respect to PSAK No. 50 (revised 2006) concerning the presentation and disclosure of financial instruments and PSAK No. 55 (revised 2006) concerning the recognition and measurement of financial instruments.

The dependent variable of this research is that earnings management that is proxied by discretionary accrualsused the model of special accrual Beaver et al. (1996). Components of total accruals consist of the allowance for credit losses (allowances for loans losses) and the corresponding loan loss provisions in the rules of the allowance bank earning assets (PPAP) according to Bank Indonesia Regulation (PBI) No.7/2/PBI/2005 dated January 20, 2006, as amended by PBI.8/2/PBI/2007 and Letter of Bank Indonesia (BI) No.13/658/DPNP/DPNP in 2011. The componentsare loanscharge-offs, loans outstanding, non performing assets, the difference in non-performing assets of the company, the allowance for company earning assets, provisionloanlosses, and equity of the company.
The control variables used are the firm size, financial leverage $(\mathrm{D} / \mathrm{E})$, market to book ratio $(\mathrm{M} / \mathrm{B})$ and institutional investors (II). Sizeis the logarithm of the company's market capitalization measured by the number of shares outstanding multiplied by the closing stock price at the end of year (Rudra, 2010 and Cheng et al., 2009). Financial leverage (D/E), calculated from the total liabilities divided by total equity (Rudra, 2010) Market to book ratio (M/B), calculated from the Market value of equity divided by the book value of equity (Rudra, 2010). Institutional investors (II), derived from the percentage of shares owned by institutional investors in the company (Balsam et al, 2002; Leuz et al., 2003; Siregar, 2006).

\section{Population and sample data collection}

Objects in the research were all banking companies that have go public, listed and have financial reporting at the Indonesia Stock Exchange (IDX) during the period 20082011 as many as 31 companies. Data obtained from the Indonesia Stock Exchange. The sampling technique used was purposive sampling with consideration of certain criteria. Based on these criteria, the number of samples that meet the criteria of the 23 companies. The collection of data used in the form of data files or secondary data obtained from the annual financial statements of listed companies on the Indonesia Stock Exchange and are available at (http://www.idx.co.id/) years 2008-2011. 


\section{Analysis of data}

The study used two models, the first model to test the effect of the adoption of IFRS on earnings management through multiple regression analysisand the second model to test differences in the level of earnings management before and after IFRS adoption using different test t-test. Statistical analysis using SPSS.The results of analysis, descriptive statistics and hypothesis testing techniques.

\section{RESULTS}

\section{Descriptive statistical analysis and test} classical assumption

According to Table 1 the results of the descriptive statistics show that the average (mean) discretionary accruals for the banking firm 26.03 with a standard deviation of 2.37. Based on 92 sample observations in the study, the greatest value of discretionary accruals (maximum) is 30.15 and the smallest value of discretionary accruals (minimum) is 20.45 .

Tabel 1. Descriptive Statistics

\begin{tabular}{lccccc}
\hline \multicolumn{1}{c}{ Description } & $\mathbf{N}$ & Minimum & Maximum & Mean & Standard Deviation \\
\hline IFRS & 92 & 0,00 & 1,00 & 0.50 & 0,50274 \\
LnSize & 92 & 24,48 & 32,92 & 29,1963 & 2,09213 \\
D/E & 92 & $-31,53$ & 15,92 & 8,5430 & 5,22180 \\
M/B & 92 & $-1,74$ & 5,89 & 2,0112 & 1,25120 \\
II & 92 & 20,73 & 100,00 & 97,4009 & 12,82570 \\
LnDA & 92 & 20,45 & 30,15 & 26,0359 & 2,37344 \\
\hline
\end{tabular}

The test results demonstrate the early classical assumptions are variables that do not meet either the classical assumption of normality test, autocorrelation, multicollinearity, and heteroscedasticity. Thus, by using data transformation in the form of the natural logarithm to obtain better test results and valid. The results of normality test (with one sample Kolmogorov-Smirnov test), multicollinearity and autocorrelation shown in Table 2. Kolmogorov-Smirnov significance value 0.610 is greater than the probability of significance (Asymp.Sig) $\alpha=0.05$, we conclude the data is normally distributed with the form of the natural logarithm. Variable tolerance value is below 0.10 and the value of the variance inflation factor (VIF) is above 10 (VIF $\geq 10)$, it was concluded there was no multicollinearity among the variables in the model. Similarly, to detect the presence or absence of autocorrelation through the DurbinWatson test (DW test). Durbin-Watson test results demonstrate the value of 1.219 (where the DW rate between -2 to +2 ), we can conclude there is no autocorrelation. 
Tabel 2. Classical assumption test results

\begin{tabular}{lcl}
\hline Description & Significance Value & Standard Significance \\
\hline $\begin{array}{l}\text { Test for normality(kolmogorov-smirnov } \\
\text { test) }\end{array}$ & 0,616 & Asymp. Sig. (2-tailed) $>0,05$ \\
Autocorrelation test (Durbin-Watson test) & 1,264 & score DW between -2 to +2 \\
Multicollinearitytest & & \\
Tolerance value & & \\
IFRS & 0,938 & valuetolerance $\leq 0,10$ \\
LnSIZE & 0,596 & valuetolerance $\leq 0,10$ \\
DE & 0,798 & valuetolerance $\leq 0,10$ \\
MB & 0,612 & valuetolerance $\leq 0,10$ \\
II & 0,692 & valuetolerance $\leq 0,10$ \\
IFRS & & \\
LnSIZE & 1,066 & value VIF $\geq 10$ \\
DE & 1,678 & value VIF $\geq 10$ \\
MB & 1,254 & value VIF $\geq 10$ \\
II & 1,633 & value VIF $\geq 10$ \\
& 1,445 & value VIF $\geq 10$ \\
\hline
\end{tabular}

Heteroscedasticity test results can be seen in Figure 1 graph scatterplot. Based on the scatterplot graph it appears that the dots spread randomly and scattered both above and below the 0 on the $y$-axis This shows that there is no heteroscedasticity in the model.

Figure 1. scatterplot grafic

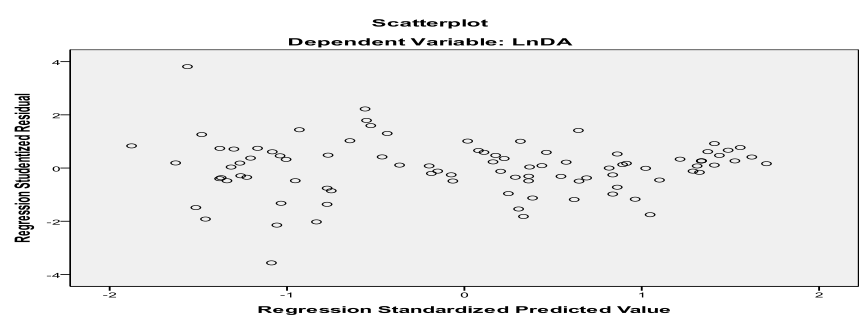

\section{Results of hypothesis testing}

Based on the test results of $t$-statistic in Table 3 for testing the first hypothesis can be concluded that the independent variables that IFRS has a negative but not significant effect on earnings management. It can be seen from the results of the analysis the value of $t$ countfor the variable IFRS amounted to 1.917 while the value of t-table at a rate of $5 \%$ for 1.988 significance. Comparing the calculated of value of t-count obtained with the value of $\mathrm{t}$-table show that the value of $\mathrm{t}$-count is smaller than $\mathrm{t}$-table (-t count $>\mathrm{t}$-table). Then, the significance value obtained is 0.059 greater than 0.05.Variable institutional investors also showed no significant, where the value of a significance level of 0.103 ( $p>0.05$ ). This indicates that the variable is IFRS and institutional investors have no significant effect on the change (variance) of earnings 
management. As for the three other control variables, has a significant positive effect on the earnings management variable size that shows the value of the significance level of $0.000(\mathrm{p}<0.05)$ and a variable value of debt to equity showed a significance level of 0.003 (p $<0.05)$. Variable market to book value shows a significant negative effect on earnings management with value significance level of $0.000(\mathrm{p}<0.05)$.

Tabel 3. The results ofthe statistical test

\begin{tabular}{ccccc}
\hline Variable & Coefficient value & tstatistic value & Significance value & Description. \\
\hline (Constant) & $-8,038$ & $-4,977$ & 0,000 & \\
IFRS & $-0,378$ & $-1,917$ & 0,059 & rejected \\
LnSIZE & 1,244 & 20,936 & 0,000 & acceptable \\
DE & 0,63 & 3,054 & 0,003 & acceptable \\
MB & $-0,570$ & $-5,815$ & 0,000 & acceptable \\
II & $-0,015$ & $-1,647$ & 0,103 & rejected \\
\hline
\end{tabular}

Based on the results of different test ttest in Table 4, to test the second hypothesis showed the average value of discretionary accruals in the period before the adoption of IFRS amounted to 25.90 while the average value of discretionary accruals in the period after the adoption of IFRS amounted to 26.16. Then, the results show the value of t-statistic of
1.575 with a significance of 0.122 . Significance probability value (sig 2-tailed) of 0.122 is greater than the significance level $\alpha=$ 0.05 , it can be concluded that although there are differences in the absolute value of discretionary accruals on average, there were no statistically significant differences.

Tabel 4. The results ofdifferent testt-testt

\begin{tabular}{cccc}
\hline & \multicolumn{2}{c}{ Paired Samples Statistics } \\
Description & Mean & Std. Deviation & Std. Error Mean \\
\hline Pair 1Before & 25,9024 & 2,39088 & 0,35252 \\
after & 26,1694 & 2,37462 & 0,35012 \\
& \multicolumn{2}{c}{ Paired Samples Test } \\
Pair 1 & $-0,26704$ & 1,14979 & 0,16953 \\
Before-After & & & \\
t-statistic & 1,575 & & \\
Sig. (2-tailed) & 0,122 & & \\
\hline
\end{tabular}




\section{DISCUSSION}

This research shows that the adoption of IFRS did not significantly influence earnings management. With the application of IFRS does not indicate there is a decrease of earnings management. This research also included some control variables such as: size, financial leverage, market to book value and institutional investors. Among the four control variables, the institutional investors are found not to be significant, while the other three significant variables. Size and financial leverage shows a positive effect on earnings management. Market to book value indicates a negative effect on earnings management. The results of the different test analysis conducted also show that statistically there is no difference in the level of earnings management significantly between before and after the adoption of IFRS.

The first hypothesis testingshowed thatthere was no significant effect of IFRS on the value of the variable accrual discreationary banks observed. Regression coefficient of variableIFRS shows a negative relationshipbetween IFRS discreationary accrualvalue, where the greater the value of the variable IFRS, the value discreationary accrual will be smaller, and vice versa. However, because the statistics show that this variable is not significant then the first hypothesis which states that the adoption of IFRS negatively affect earnings management can not be accepted. The results of this study are consistent with results of previous studies (Rudra, 2011) which did not find a decrease to earnings management.

When viewed from the component value of Non-Performing Assets (NPA) were found in this research there is a decline in value after IFRS adoption than before the adoption of IFRS. This is in line with research Anggraita (2012) who also found a decrease in earnings management, particularly in components allowance for impairment losses as a component in the calculation of earnings management proxy. However, note that the components of Non Performing Assets (NPA) orcomponent of impairment losses (allowance for impairment) is only one part of all the components of total accruals can be calculated. There are still other accrual components as well, such as loanscharge-offs, loans outstanding, and others. It can be an alternative option for the management of conduct earnings management. Myer (1990), Betty et al. (1995), and Collins et al. (1995) cited in Anggraita (2012) found evidence that management does earnings management to meet the capital adequacy using theloanscharge-offs.

Whardani (2009) revealed that the adoption of IFRS international accounting standards ensures high-quality reporting, because it is made according to international standards that are supported by the IASB as a standard setter competent world-class, but on 
the other hand, the adoption of IFRS will not necessarily be able to accommodate the special characteristics of a countries. This happens because the IASB as a standard setter of IFRS has members who are mostly developed countries. Therefore, IFRS may not be entirely appropriate when implemented in a country that has different characteristics with the developed countries, so that the adoption of IFRS should be tailored to the characteristics of a country in order to accommodate the process of harmonization of the different characteristics of the country. Inconsistency in the application of IFRS adoption is a country with characteristics that can lead to failure to achieve the purpose of the creation of this standard, the one as simplifiers accounting policy alternatives are allowed and expected to limit the consideration of policy management to manipulation earnings (earnings management) so as to improve the quality of profit. Therefore, in order to be an effective application of the adoption of IFRS and in accordance with the goals and positively impact financial reporting it is necessary to take into consideration the different characteristics, in terms of both the company and the country at large. As in the approach of positive accounting theory that the standard choice by management, by analyzing the costs and benefits of certain financial disclosures related to various individuals and resource allocation in the economy. In this case, the analysis can be related to the environment in a country such as the characteristics of the company, the system of law enforcement, and market conditions, in addition to the applicable standards.

Research was also conducted using different test t-test with paired samples test analyzes indicate that there are differences in the absolute value of the average, where the average value of discretionary accruals in the period after the adoption of IFRS is greater than the average value of discretionary accruals before adoption of IFRS. However, this difference was not statistically significant. This finding is not in accordance with the expectations of the research that there is a decrease in earnings management after IFRS adoption.

Anggraita (2012) revealed that the implementation of PSAK No. 50 and PSAK No. 55 (revised 2006) may increase the likelihood of earnings management through the management does allowance for impairment. This is because of the prohibition of reclassification of financial instruments between strict lead reduction in space for management to perform income smoothing through a reclassification between groups of instruments. Although the calculation of allowance for impairment under PSAK No. 50 and PSAK No. 55(revised 2006) over more rigorous and objective than previous GAAP, however, contain elements of judgmentis 
higher, thus increasing the likelihood of earnings management to do management.Beatty et al. (1999) also found that managers use discretion to set the time of the realization of gains and losses from securities owned. Because the gains or losses from financial instruments is an alternative tool to perform earnings management than through the allowance for impairment.

\section{CONCLUSIONS AND RECOMMENDATIONS}

Based on the findings in this study that specifically examined the banking sector, the result that the adoption of IFRS did not significantly influence earnings management. With the application of IFRS does not indicate there is a decrease of earnings management. The results of the different test analysis conducted also show that statistically there is no difference in the level of earnings management significantly between before and after the adoption of IFRS. This finding is not in accordance with the expectations of the research that there is a decrease in earnings management after IFRS adoption. It can be concluded that the standard adjustment by adopting IFRS in particular, PSAK No.50 (revised 2006) concerning the presentation and disclosure of financial instruments and PSAK No. 55 (revised 2006) concerning the recognition and measurement of financial instruments yet still allow for the occurrence of earnings management. The difference in the characteristics of a company or the country in general may also lead to the implementation of IFRS adoption is not effective. The state of corporate forms, state forms, economic conditions and market developments may be other considerations that indicate the practice of discretionary accruals actually increased since the period of implementation. IFRS may not be entirely appropriate when implemented in a country that has different characteristics. Another factor that can also be considered through the findings of this study is the timing of the standard. The adoption of IFRS is still new force in Indonesia, the possibility has not been fully and effectively implemented as a whole so it is still possible for the occurrence of earnings management.

Thus, it is advisable for practitioners, such as Bank Indonesia and Bapepam to consider the characteristics of the bank in setting policy regarding financial reporting, particularly with regard to financial instruments that banks are a crucial part of the banking sector in order to run more effectively. Similarly, for the IAI, the results of this study can be used as consideration related to the formulation of accounting standards to the adoption of IFRS standard. 


\section{REFERENCES}

Anggraita, Viska. (2012). The impact ofPSAK50/55(Revised

2006)TowardProfit

ManagementinBanking: The Role ofCorporateGovernanceMechanism, OwnershipStructureandAuditQuality. Journal ofthe NationalSymposium onAccounting (SNA) XVBanjarmasin.

Ball, R., Kothari, S. dan Robin, A. (2000). The Effect of International Institutional Factors on Properties of Accounting Earnings. Journal of Accounting and Economics 29, 1-52.

Robin, A. dan Joanna S.W. (2003). Incentives Versus Standards: Properties of Accounting Income in Four East Asian Countries. The Journal of Accounting and Economics.

Balsam, S., Bartov, E. dan Marquardt, C. (2002). Accruals Management, Investor Sophistication, and Equity Valuation: Evidence from 10-Q Fillings. Journal of Accounting Research Vol.40 No.4, hlm. 9871012.

Barth, M., Landsman, W. dan Lang, M. (2007). International Accounting Standards and Accounting Quality. Journal of Accounting Research, 46(3), 467-498

Beatty, A., dan Haris, DG. (1995). The effects of taxes, Agency costs, and information asymmetry on earnings management: A comparison of Public and Private Firms. Review of Accounting Studies, 4, 299-326.

Beaver, W.H., dan Engel, E.E. (1996). Discretionary Behavior with Respect to Allowances for Loan Losses and the Behavior of Security
Prices.Journal of Accounting and Economics 22 (1996) 177-206.

Belkaoui, Ahmed Riahi. 2001. Teori Akuntansi, Buku 2. Jakarta: Salemba Empat.

Burgstahler, D., Luzi, H. dan Christian, L. (2006). The Importance of Reporting Incentives: earnings Management in European Private and Public Firms. The Accounting Review, October 2006.

Cai, L., Asheq, R. dan Courtenay, S. (2008). The Effect of IFRS and its Enforcement on Earnings Management: An International Comparison. Social Science Research Network Electronic Paper Collection, (Online), (http://ssrn.com/abstract=1473571, diakses 28 Februari 2012).

Callao, S., dan Jarne, J. (2010). Have IFRS Affected Earnings Management in The European Union?, Journal of Accounting in Europe Vol. 7, No. 2, 159-189, December 2010.

Caratri, Endah. (2011). Implikasi Penerapan PSAK 50 dan 55 Revisi 2006 Pada Dunia Perbankan. (Online), (http://vibizmanagement.com/colum $\mathrm{n}$ /index/category/financial /2366 diakses 09 September 2012).

Cheng, Q., Warfield, T. dan Ye, M. (2009). Equity Incentives and Earnings Management: Evidence from the Banking Industry. CAAA Annual Conference 2009 Paper.Social Science Research Network Electronic Paper Collection, (Online), (http://ssrn. com/abstract $=1326558$, diakses 28 Februari 2012).

Christensen, H.B., Lee, E. dan Walker, M. (2008).Incentives or Standards: What 
DeterminesAccountingQualityChang esAround IFRS Adoption?.Social Science Research Network Electronic Paper Collection, (Online), (http://ssrn.com/abstract $=1013054$, diakses 28 Februari 2012).

Daske, H. dan Gebhardt, G. (2006). International Financial Reporting Standards and Experts Perceptions of Disclosure Quality. Abacus 42(3-4), 461-498.

Ding, Y., Hope, O., Jeanjean, T. dan Stolowy, H. (2007). Differences between domestic accounting standards and IAS: measurement, determinants and implications. Journal of Accounting and Public Policy, 26(1), 1-38.

Ewert, R. dan Wagenhofer, A. (2005). Economic Effects of Tightening Accounting Standards to Restrict Earnings Management. The Accounting Review. Vol. 80, No.4 2005. Pp. 1101-1124.

Haryono, Slamet. (2008). Effect ofOpportunisticMotif,

SignalingandRegulationAgainstCapit alAllowanceon Earning Assets(StudyonCommercialBanksinIn donesia). DissertationDoctoral Programin

EconomicsDiponegoroUniversity.

Hung, M. dan Subramanyam, K. (2007). Financial Statement Effects of Adopting International Accounting Standards: The Case of Germany. Working Paper, University of Southern California.

Jeanjean, T. dan Stolowy, H. (2008). Do Accounting Standards Matter? An Exploratory Analysis of Earnings Management Before and After IFRS Adoption. Journal of Accounting and Public Policy, 27, 480-494.
Jensen, M.C dan Meckling, W.H. (1976). Theory of The Firm: Managerial Behavior: Agency Cost and Ownership Structure. Journal of Financial Economic. Vol.3, No.4, Hlm. 305-360.

Leuz, C., Nanda, D. dan Wysocki, P.D. (2003). Earnings Management and Investor Protection: an International Comparison. Journal of Financial Economics, 69, 505-527.

Lin, H. dan Paananen, M. (2006). The Effect of Financial Systems on Earnings Management among Firms Reporting under IFRS. Business School Working Papers UHBS 2006.

Lippens, M. (2010). The Mandatory Introduction of IFRS as a Single Accounting Standard in the European Union and the Effect on Earnings Management. InBook, 81-103.

Macey dan O'Hara. (2003). The Corporate Governance of Banks. Federal reserve Banks Policy Review. Vol. 9. No. 1.

Oriol, A. dan Gowthorpe, C. (2005). Creative Accounting: Nature, Incidence and Ethical Issues.Universitat Pompeu Fabra, BarcelonaJournal of Economic Literature classification: M41.

Rudra, Titas. (2011). Does IFRS Influence Earnings Management? Evidence from India. Journal of Management Research Finance and Control Group, Indian Institute of Management Calcutta. ISSN 2012, Vol.4, No.1:E17.

Scott, William R. 1997. Financial Accounting Theory. Prentice Hall. 
Siregar, Silvia. (2006). Effect ofOwnership Structure,

CorporateSizeandCorporateGoverna ncePracticestoManageEarnings(Earni ngs Management). Journal ofAccountingResearchIndonesia. Vol.9, no. 3,September 2006. It307326.

Soderstrom, N.S. dan Sun, K.J. (2007). IFRS Adoption and Accounting Quality: a Review. European Accounting Review. 16(4), 675-702.

Sulistyanto, Sri. (2008). ProfitManagement: Theory andEmpirical Model. Jakarta:PT. Grasindo.

Tsalavoutas, Ioannis. (2010). Transition to IFRS and Value Relevance in A
Small But Developed Market: A Look at Greek Evidence. Departement Accounting and Finance. Published In La Place De La Dimension Europeenne Dans La Comptabilite Controle Audit, Strasbourg: France Halshs-00460532, Version 1- 1 Mar 2010.

Wardhani, Ratna. (2009). Effect ofProtectionForInvestors,

Convergence ofAccounting Standards, Implementation ofCorporateGovernance, andAuditQualityon the Quality ofEarnings: Analysis ofCrossCountry In Asia. DissertationDoctoral Programin Accounting, University of Indonesia 